Website: http://journal.hibiscuspublisher.com/index.php/AJPB/index
PUBLISHER

\title{
Isolation and Characterization of a Molybdenum-reducing and Carbamate-degrading Serratia sp. strain Amr-4 in soils from Egypt
}

\author{
AbdEl-Mongy, M. Abd. ${ }^{1}$, Rahman, M.F. ${ }^{1}$ and Shukor, M.Y.*2 \\ ${ }^{1}$ Microbial Biotechnology Department, Genetic Engineering and Biotechnology Institute, Sadat City University, Egypt. \\ ${ }^{2}$ Department of Biochemistry, Faculty of Biotechnology and Biomolecular Sciences, Universiti Putra Malaysia, UPM 43400 Serdang, \\ Selangor, Malaysia. \\ *Corresponding author: \\ Prof Dr. Yunus Shukor, \\ Department of Biochemistry, \\ Faculty of Biotechnology and Biomolecular Sciences, \\ Universiti Putra Malaysia, \\ UPM 43400 Serdang, \\ Selangor, \\ Malaysia. \\ Email: yunus.upm@gmail.com / mohdyunus@upm.edu.my
}

\section{HISTORY}

Received: $15^{\text {th }}$ Oct 2021

Received in revised form: $18^{\text {th }}$ Dec 2021 Accepted: 24th Dec 2021

\section{KEYWORDS}

Molybdenum-reducing

Cerratia sp.

Carbamate

Carbaryl

\begin{abstract}
Physical or chemical procedures could efficiently remove contaminants including pesticides such as carbamates from high concentrations of toxicants. Bioremediation, on the other hand, is frequently a less expensive option in the long term when used at low concentrations. Isolation of multiple toxicants removing microorganisms is the goal of bioremediation. In this paper we report on the molybdenum reduction of the bacterium and its ability to grow on the carbamates carbofuran and carbaryl as carbon sources. Both the carbamates carbofuran and carbaryl cannot support molybdenum reduction when used as the sole carbon sources. Between pH 6.0 and 6.8 and between 30 and $34^{\circ} \mathrm{C}$, the bacterium is most efficient in converting molybdate to Mo-blue. For molybdate reduction, glucose was shown to be the strongest electron donor, with maltose and sucrose coming in second and third, respectively, and d-mannitol and d-adonitol coming in last. Phosphate concentrations of 2.5 to $7.5 \mathrm{mM}$ and molybdate concentrations of 20 to $30 \mathrm{mM}$ are also needed. Identical to that of a decreased phosphomolybdate, the Mo-blue produced by the new Mo-reducing bacteria has an absorption spectrum similar to prior Mo-reducing bacteria. Inhibition of molybdenum reduction was $73.3,50.1,50.1$ and 20.7 percent, respectively, by mercury, copper, silver and lead at $2 \mathrm{ppm}$. The bacterium was tentatively identified as Serratia sp. strain Amr-4 after biochemical investigation. This bacterium's ability to detoxify a variety of toxicants is highly sought after, making it a significant bioremediation agent.
\end{abstract}

\section{INTRODUCTION}

Pesticides based on carbamate have a fascinating history of research and discovery. Calabar bean paste, which is rich in carbamate alkaloids, was employed in West Africa to determine whether or not a person was guilty or innocent of witchcraft accusations. After being forced to consume calabar bean paste, the suspected 'witches' either died or were deemed innocent. In the calabar bean, physostigmine was shown to be the active carbamate carbamate, according to research. Indeed, the West African term for calabar bean, esere, is eserine's counterpart. A series of carbamate insecticides was originally created in the midto late 1940s in an attempt to create new insect repellents, but their insecticidal qualities were immediately discovered and recognized [1-6]. In agriculture, the carbamate chemicals are esters of carbamic acid. N-methylcarbamates are the name given to these substances. Weed killers often make use of carbamic acid and its derivatives thiocarbamic acid and dithiocarbamic acid. To the advantage of society, carbamate insecticides safeguard and boost agricultural productivity and protect human and animal health from insect-vector-mediated illnesses when applied appropriately. Nevertheless, excessive exposure to these chemicals may lead to pesticide poisoning in people and animals. The acetylcholinesterase enzyme is inhibited by N-methylcarbamate pesticides. Hypercholinergic activity, as a consequence, is a poisonous indication. N-methyl-d-aspartate receptors are likewise hyperactivated by triggering a series excitotoxicity. Carbamate poisoning is normally treated within six to $24 \mathrm{~h}$ for both humans and animals. Atropine sulphate is the mainstay of treatment [7-12].

These pesticides contain carbamate insecticides, which are made up of carbamate and an ester group. Carbonyl, aldicarb and fenoxycarb are only few of the chemicals that make up this group. Anti-acetylcholine esterase enzyme inhibitors cause the buildup 
of acetylcholine at synapses [13]. Among the carbamates, carbofuran is one of the most toxic insecticides registered in some parts of the world. Carbofuran is displayed high mammalian toxicity with an $\mathrm{LD}_{50}$ of $2 \mathrm{mg} / \mathrm{kg}$ in mice, while carbaryl is a broad-spectrum insecticide often used in the agricultural sector.

Acetyl cholinesterase activity is permanently inhibited by both pesticides. Mammalian liver metabolic activities such as protein synthesis, glucose metabolism, and detoxification have been shown to be affected by nontarget toxicity [13]. This medicine is also known as a mild inducer of hepatic microsomal drug metabolism (WHO) activity. Both carbamates are very mobile in soil, and excessive usage of them might have detrimental effects on non-targeted creatures and human health. Numerous researches have been conducted on how to remove them from the environment as a result [14-21].

Molybdenum is one of the necessary heavy metals that is required in small levels but is hazardous to a wide range of species when in large quantities. It is one of the necessary heavy metals that is required in small amounts but is harmful to a wide range of species when in large quantities. Molybdenum disulphide is used as an alloying agent, as an anti-freeze component in automotive engines, and as a lubricant in the form of molybdenum disulphide, among many other industrial applications. As a result of the widespread use of molybdenum in industry, there have been a number of instances of water contamination. On the ground, however, it has been demonstrated to be a significant contaminant in sewage discharge that has been polluted [22-26].

Molybdenum has been proven to disrupt spermatogenesis and to delay embryogenesis in species such as catfish and mice at concentrations as low as a few parts per million of the elements. In addition, molybdenum is extremely toxic to ruminants, particularly cows, even at low concentrations of a few parts per million or less [27-31]. Even if physical or chemical treatments may be effective at larger concentrations (e.g., eliminating heavy metals), bioremediation is more cost-effective in the long run, particularly at lower concentrations of contaminants. In the past, it has been demonstrated that the degradation of xenobiotics and heavy metals operate in concert. However, despite the fact that sodium dodecyl sulphate (SDS) does not allow for the reduction of molybdenum, a molybdenumreducing bacteria was found to be able to thrive when SDS was used as the only carbon source. The use of non-native microorganisms in bioremediation is discouraged since it has the potential to cause ecological issues. As a result, it is advised that local bacteria be screened in advance of cleanup activities $[32,33]$.

It is our goal in this study to determine if a unique molybdenumreducing bacteria isolated from polluted soils can reduce molybdenum on its own, either even without the assistance of a pesticide, by using pesticides as electron donors for reduction or as carbon sources for growth.

\section{MATERIALS AND METHODS}

\section{Chemicals}

All chemicals were of analytical grade unless stated otherwise.

\section{Isolation of molybdenum-reducing bacterium}

A polluted land site in Sadat City, Egypt, was sampled $(5 \mathrm{~cm}$ deep from the topsoil) in 2014. A single gramme of dirt was dissolved in sterile tap water for the analysis. At room temperature for 48 $\mathrm{h}$, the soil in tap water suspension was pipetted and distributed on agar with a medium of low phosphate $(\mathrm{pH} 7.0)$. As a result, the low phosphate media (LPM) was composed of glucose (1 percent), $\left(\mathrm{NH}_{4}\right)_{2} . \mathrm{SO} 4$ (0.3 percent), $\mathrm{MgSO}_{4} .7 \mathrm{H}_{2} \mathrm{O}$ (0.05 percent) and yeast extract $(0.5$ percent), as well as sodium chloride $(0.5$ percent $), \mathrm{NaCl}(0.5$ percent $)$ and $\mathrm{Na}_{2} \mathrm{HPO}_{4}(0.071$ percent or 5 $\mathrm{mM}$ ) [34]. Molybdate reduction by molybdenum-reducing bacteria is shown by the presence of blue colonies. It was isolated and restreaked on LPM to get a pure culture of the organism (low phosphate media). It took 48 hours at room temperature on an orbital shaker set at $120 \mathrm{rpm}$ for the same medium to decrease molybdenum in liquid media using the same procedure $(\mathrm{pH} 7.0)$. $1.0 \mathrm{~mL}$ of Mo-blue was obtained by centrifuging the liquid culture at $10,000 \mathrm{xg}$ for 10 minutes at room temperature, yielding $1.0 \mathrm{~mL}$ of Mo-blue for analysis. UV-spectrophotometer 400-900 $\mathrm{nm}$ scan of supernatant (Shimadzu 1201). We utilised low phosphate medium for baseline correction.

\section{Partial identification of the Mo-reducing bacterium}

In order to identify the bacterium, standard methods such as size and colour on nutrient-agar plates, Gram staining, motility and other biochemical tests were used [35]. The ABIS online system was utilized to interpret the results [36].

\section{Preparation of resting cells for molybdenum reduction characterization}

It was done in the same manner as previously, using a microplate or microtiter format, to undertake a range of molybdenum reduction to Mo-blue characterisation tests. These included the effects of temperature, phosphate, $\mathrm{pH}$, and molybdate concentrations, among other things. The specific extinction coefficient was used to quantify the amount of Mo-blue that was produced by the medium in a microplate configuration where the value of $11.69 \mathrm{mM} .^{-1} \cdot \mathrm{cm}^{-1}$ at 750 was used [37]. Heavy metals from commercial salts or from Atomic Absorption Spectrometry standard solutions from MERCK were utilized in this study. The capability of several pesticides to provide for molybdenum reduction as source of electron was analyzed using the microplate format with substituting the glucose from the LPM with these xenobiotics at $200 \mathrm{mg} / \mathrm{L}$ final concentration. Non-water soluble pesticides were dissolved in methanol as the carrier solvent [38].

\section{Statistical analysis}

Means \pm standard deviation of tripilates are used in the calculation of values. Comparing groups was done using a Student's t-test or a one-way analysis of variance followed by a Tukey's post hoc analysis. Statistical significance was defined as a $\mathrm{P}<0.05$.

\section{RESULTS AND DISCUSSIONS}

\section{Identification of Mo-reducing bacterium}

Based on standard biochemical and physiological methods, the microorganism was a Gram-negative, facultative anaerobe, rodshaped, motile microorganism. Approximately 1 to $3 \mathrm{~mm}$ in diameter, the colonies had a glossy cream-white appearance, and were smooth and round in shape. Comparing the results of numerous biochemical and morphological tests helped identify the bacterium (Table 1) to the Bergey's Manual of Determinative Bacteriology [35] and using the ABIS online software [36]. TSerratia plymuthica was the most accurate and homologous of the four possible bacterial identities suggested by the programme. The assignment to the species level is not possible at this time. In order to identify this species further, additional research, including a comparison of the 16srRNA gene by molecular identification, is required. As of right now, the bacterium is temporarily identified as Serratia sp. strain Amr-4. 
Table 1. Biochemical tests for Serratia sp. strain Amr-4.

Motility
Pigment
Catalase production (24 h)
Oxidase ( 24 h)
ONPG (beta-galactosidase)
Lysine decarboxylase (LDC)
Ornithine decarboxylase (ODC)
Arginine dihydrolase (ADH)
Nitrates reduction
Voges-Proskauer (VP)
Indole production
Methyl red
Hydrogen sulfide (H2S)
Malonate utilization
Acetate utilization
Tartrate (Jordans)
Citrate utilization (Simmons)
Gelatin hydrolysis
Esculin hydrolysis
Deoxyribonuclease
Urea hydrolysis
Lipase (corn oil)
Phenylalanine deaminase

Acid production from:

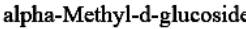

D-Adonitol

Dulcitol

Glycerol

Cellobiose

d-Glucose, acid

Lactose

Maltose

myo-Inositol

d-Mannitol

Melibiose

d-Mannose

Raffinose

Mucate

Salicin

1-Rhamnose

Sucrose

d-Sorbito

Trehalose

d-Xylose
L-Arabinose

Other bacteria's Mo-blue spectra also follow this rule, as we have shown [53]. In this study, the absorption spectra clearly indicate a comparable spectrum, which supports the idea. The complicated structure of the phosphomolybdate compound necessitates the use of n.m.r. and e.s.r. for precise identification.

Heteropolymolybdate species can be characterised using spectrophotmetric methods such as scanning spectroscopic profiles. [57]. Even though Mo-maximal blue's absorption wavelength was $865 \mathrm{~nm}$, routine monitoring of its synthesis at $750 \mathrm{~nm}$ was sufficient due to the intensity achieved being significantly higher than $600-620 \mathrm{~nm}$, which is the range cellular maximum absorption [38]. Earlier determination of Mo-blue production utilizes a number of wavelengths such as $820 \mathrm{~nm}$ [54] and $710 \mathrm{~nm}[58]$

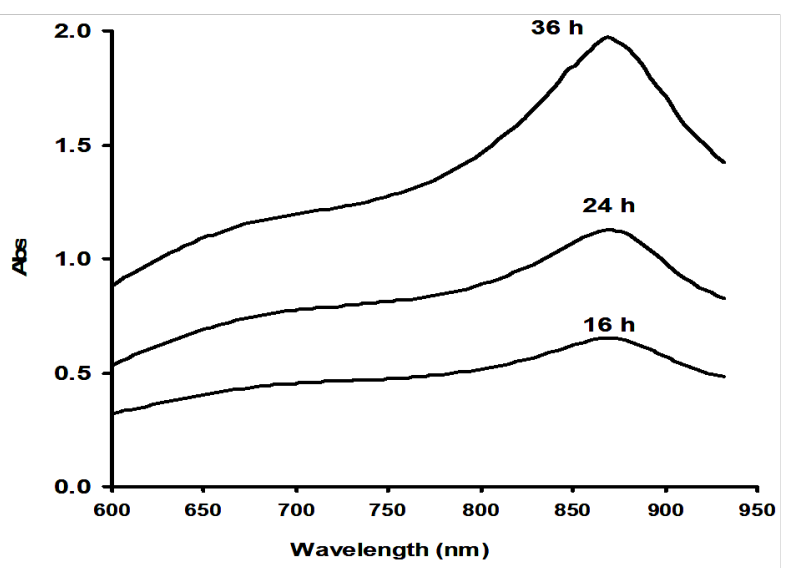

Fig. 1. Absorption spectra of Mo-blue scanned from 500 to $950 \mathrm{~nm}$ from Serratia sp. strain Amr-4 at various growth stages.

\section{Effect of pH and temperature on molybdate reduction}

Varied buffers were used to incubate Serratia sp. strain Amr-4 at different $\mathrm{pH}$ levels, ranging from 5.5 to 8.0. (20 mM). An ANOVA study found that the ideal $\mathrm{pH}$ range for reducing was between 6.0 and 6.8." (Fig. 2). An optimal temperature ranged from 30 to $34{ }^{\circ} \mathrm{C}$ with no significant difference $(\mathrm{p}>0.05)$ between values recorded as analysed using ANOVA (Fig. 3) spanning the range of 20 to $60{ }^{\circ} \mathrm{C}$. Serratia sp. strain Amr-4 was unable to produce Mo-blue at temperatures over $34^{\circ} \mathrm{C}$.

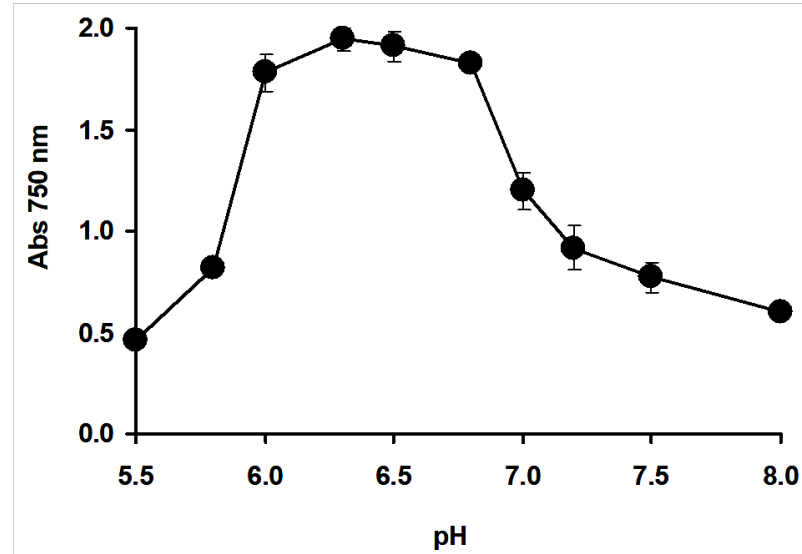

Fig. 2. Effect of pH on Mo-blue production by Serratia sp. strain Amr-4. Error bars are \pm standard deviation $(n=3)$. 


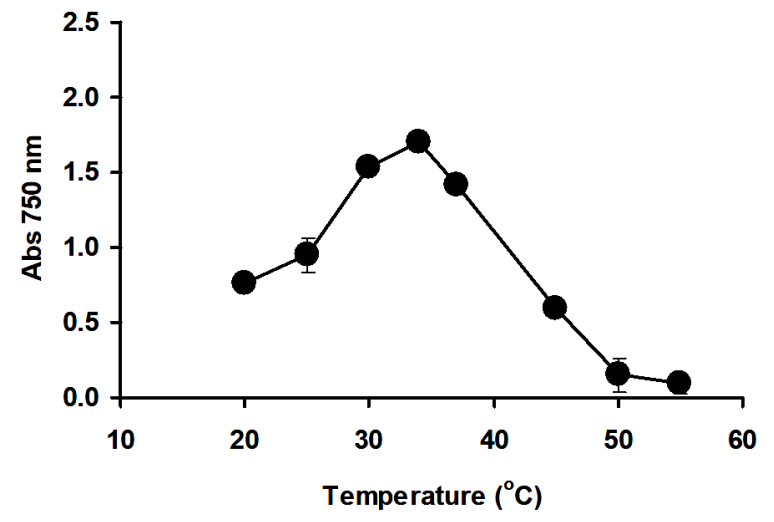

Fig. 3. Effect of temperature on Mo-blue production by Serratia sp. strain Amr-4. Error bars are \pm standard deviation $(n=3)$.

Temperature and $\mathrm{pH}$ alter enzyme activity and protein folding, resulting in the suppression of molybdenum reduction, which is an enzyme-mediated process. Serratia sp. strain Amr-4 may be a promising choice for soil bioremediation of molybdenum in both the local and international contexts. The bulk of the reducers operate well at temperatures ranging between 25 and 37 degrees Celsius [39,56,59-68] with a psychrotolerant reducer showing an optimal temperature sbetween 15 and $20^{\circ} \mathrm{Cas}$ it was isolated from Antarctica [69].

When it comes to supporting molybdenum reduction, Serratia sp. strain Amr-4 has an ideal pH range that corresponds to the bacterium's ability to function as a neutrophile. The ability of neutrophils to develop between $\mathrm{pH} 5.5$ and 8.0 is one of their distinguishing properties. The best $\mathrm{pH}$ for molybdenum reduction in bacteria is somewhat acidic, with optimal pHs ranging from $\mathrm{pH} 5.0$ to $\mathrm{pH}$ 7.0. This is a significant fact about molybdenum reduction in bacteria [54,56,58-70]. The creation and stability of phosphomolybdate before it is reduced to Moblue have been postulated in the past, and it has been suggested that an acidic $\mathrm{pH}$ is necessary in this process. As a result, the optimal reduction is achieved by a delicate balance between enzyme activity and substrate stability [71].

Effect of carbon sources as electron donor for Mo reduction Earlier works of Shukor et al. indicated that the majority of the Mo-reducing bacteria prefers glucose, followed by sucrose and fructose [63]. These simple sugars produces NADH and NADPH much easier than complex carbon sources such as acrylamide or acetamide [68,72]. Glucose was the most efficient electron donor for promoting molybdate reduction, followed by maltose, sucrose, d-mannose, myo-inositol, d-sorbitol, trehalose, glycerol, salicin, d-adonitol, and d-mannitol, in that order, and then maltose and sucrose (Fig. 4). Other carbon sources were found to be insufficient for molybdenum reduction.

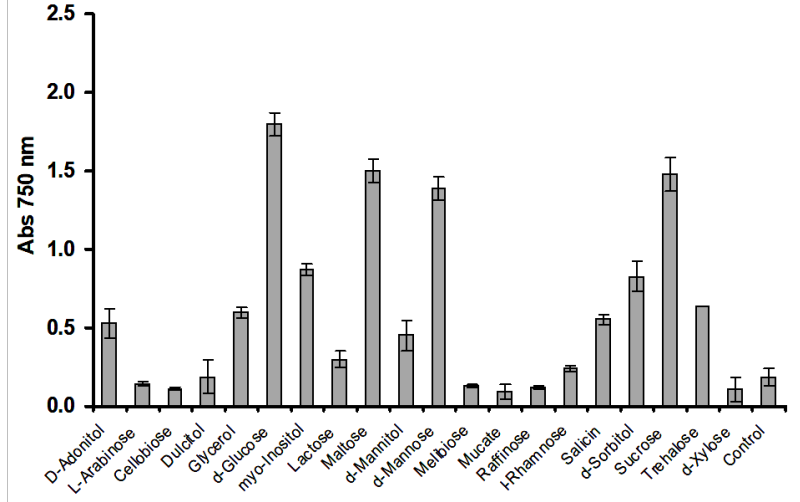

Fig. 4. The effect of different electron donor sources (1 percent weighted average) on Mo-blue production by Serratia sp. strain Amr-4. Error bars are \pm standard deviation $(\mathrm{n}=3)$.

Role of phosphate and molybdate in molybdate reduction

A balance amount of molybdenum and phosphate is critical as unbalanced level impede Mo-blue synthesis in bacteria, making this research extremely essential $[39,56,59,61-63,66,68-70]$. Phosphate was required from 2.5 to $7.5 \mathrm{mM}$ with higher concentrations were strongly inhibitory to reduction (Fig. 5). In order for the phosphomolybdate complex to be stable, it is believed that a high phosphate concentration would hinder the complex's stability.

However, this has not been shown yet. The buffering strength of the phosphate buffer, on the other hand, rises with increasing phosphate content. It is also observed that the phosphomolybdate complex is unstable when exposed to phosphate [73-75]. So far, all known bacteria that reduce molybdenum require phosphate concentrations no greater than 5 $\mathrm{mM}$ to function properly [54,56,58-70]. When the influence of molybdenum concentration on molybdenum reduction was investigated, it was shown that the newly isolated bacteria was capable of reducing molybdenum at concentrations as high as 60 $\mathrm{mM}$, albeit at the expense of Mo-blue synthesis. The best reduction range was found to be between 20 and $30 \mathrm{mM}$ (Fig. 6).

Molybdenum contamination can be reduced if the strain is reduced to an insoluble form at this high concentration. Molybdenum's optimum concentrations for supporting bacterial reduction range from 15 to $80 \mathrm{mM}[54,56,58-70]$. As a contaminant, molybdenum has a maximum concentration of roughly $20 \mathrm{mM}$ in the environment [76]. 


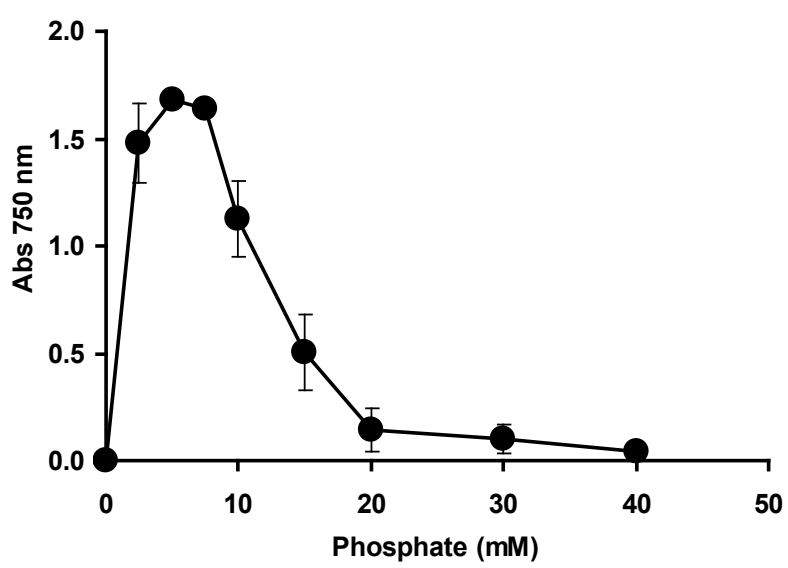

Fig. 6. Serratia sp. strain Amr-4 molybdenum reduction at various phosphate content. Error bars are \pm standard deviation $(n=3)$.

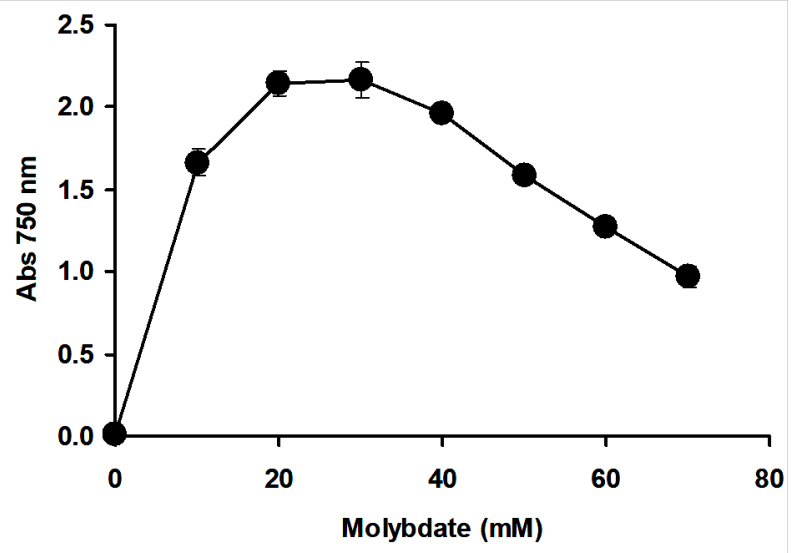

Fig. 6. The effect of molybdate concentration on molybdenum reduction by Serratia sp. strain Amr-4. Error bars are \pm standard deviation $(n=3)$.

\section{Inhibitory effect of heavy metals}

Mmercury, copper, silver and lead at 2 ppm inhibited reduction by 73.3, 50.1, 50.1 and 20.7\%, respectively (Fig. 7). Because of their inhibitory effects on bioremediation, other metal ions and heavy metals have a significant influence on the process. As a result, screening and isolation of metal-resistant bacteria are critical steps in the process. As explained earlier by Shukor et.al. [77], mercury is a true physiological inhibitor to molybdate reduction as it did not inhibit chemical reduction of molybdenum to molybdenum blue while other metal ions either inhibit or act as a promoter in producing Mo-blue from phosphomolybdate, which is a common problem in many metal reduction works involving microorganisms where careful experiments are needed to distinguish between abiotic and biological reduction [77]. Almost all Mo-reducing bacteria to date are inhibited by heavy metals (Table 2). In general, heavy metals such as silver, cadmium, mercury and copper tend to target enzymes in their sulfhydryl group [78]. Chromate can inhibit enzymes such as glucose oxidase [79]. The enzymes responsible for reducing heavy metals were rendered ineffective by heavy metal binding.

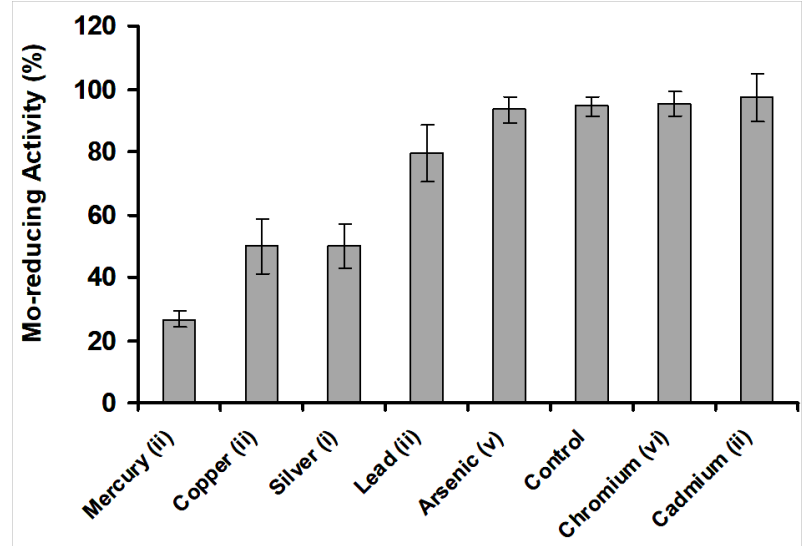

Fig. 7. The influence of metals on Serratia sp. strain Amr-4's Mo-blue synthesis. Resting bacteria cells were cultured for 48 hours under optimal conditions on a microtiter plate.. Error bars are \pm standard deviation $(\mathrm{n}=$ 3).

Table 2. Inhibition of Mo-reducing bacteria by heavy metals.

\begin{tabular}{|c|c|c|}
\hline Bacteria & Heavy Metals that inhibit reduction & Author \\
\hline Bacillus pumilus strain lbna & $\mathrm{As}^{3+}, \mathrm{Pb}^{2+}, \mathrm{Zn}^{2+}, \mathrm{Cd}^{2+}, \mathrm{Cr}^{6+}, \mathrm{Hg}^{2+}, \mathrm{Cu}^{2+}$ & [64] \\
\hline Bacillus sp. strain A.rzi & 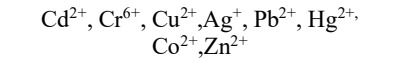 & [66] \\
\hline Serratia sp. strain Dr.Y8 & $\mathrm{Cr}, \mathrm{Cu}, \mathrm{Ag}, \mathrm{Hg}$ & [61] \\
\hline S. marcescens strain Dr.Y9 & $\mathrm{Cr}^{6+}, \mathrm{Cu}^{2+}, \mathrm{Ag}^{+}, \mathrm{Hg}^{2+}$ & [39] \\
\hline Serratia sp. strain Dr.Y5 & n.a. & {$[60]$} \\
\hline $\begin{array}{l}\text { Pseudomonas sp. strain } \\
\text { DRY2 }\end{array}$ & $\mathrm{Cr}^{6+}, \mathrm{Cu}^{2+}, \mathrm{Pb}^{2+}, \mathrm{Hg}^{2+}$ & [56] \\
\hline $\begin{array}{l}\text { Pseudomonas sp. strain } \\
\text { DRY1 }\end{array}$ & $\mathrm{Cd}^{2+}, \mathrm{Cr}^{6+}, \mathrm{Cu}^{2+}, \mathrm{Ag}^{+}, \mathrm{Pb}^{2+}, \mathrm{Hg}^{2+}$ & {$[69]$} \\
\hline $\begin{array}{l}\text { Enterobacter sp. strain } \\
\text { Dr.Y13 }\end{array}$ & $\mathrm{Cr}^{6+}, \mathrm{Cd}^{2+}, \mathrm{Cu}^{2+}, \mathrm{Ag}^{+}, \mathrm{Hg}^{2+}$ & {$[70]$} \\
\hline $\begin{array}{l}\text { Acinetobacter calcoaceticus } \\
\text { strain Dr.Y12 }\end{array}$ & $\mathrm{Cd}^{2+}, \mathrm{Cr}^{6+}, \mathrm{Cu}^{2+}, \mathrm{Pb}^{2+}, \mathrm{Hg}^{2+}$ & {$[62]$} \\
\hline $\begin{array}{l}\text { Serratia marcescens strain } \\
\text { DRY6 }\end{array}$ & $\mathrm{Cr}^{6+}, \mathrm{Cu}^{2+}, \mathrm{Hg}^{2+*}$ & [59] \\
\hline $\begin{array}{l}\text { Enterobacter cloacae strain } \\
48\end{array}$ & $\mathrm{Cr}^{6+}, \mathrm{Cu}^{2+}$ & {$[58]$} \\
\hline Escherichia coli $\mathrm{K} 12$ & $\mathrm{Cr}^{6+}$ & [54] \\
\hline Klebsiella oxytoca strain & $\mathrm{Cu}^{2+}, \mathrm{Ag}^{+}, \mathrm{Hg}^{2+}$ & [63] \\
\hline
\end{tabular}

Potential of pesticides as electron donors for Mo reduction or to support growth

Pesticides were tested to see whether they could help reduce molybdenum levels. Although molybdenum reduction was not supported by any of the insecticides, carbofuran and carbaryl grew the bacterium (Fig. 8). Carbohydrate-degrading bacteria from a variety of taxa have been identified including Rhodococcus, Sphingomonas, Sphingobium, Bosea, and Microbacterium [80] and bacterial species such as Burkholderia cepacia [81], Novosphingobium sp. [82], Sphingomonas sp. [83]. 
Carbofuran-degrading bacteria isolated from soils were subjected to a complete molecular investigation, which found numerous known bacterial taxa as well as new ones Aminobacter spp., Arthrobacter spp., Bacillus spp., Chelatobacter spp., Ochrobactrum spp., Pseudomonas spp., Ralstonia spp., Rhodanobacter spp., Rhodococcus spp. [84]. Carbofurandegrading microbes include Micrococcus arborescens, Pseudomonas aeruginosa, Brachybacterium sp. and Salsuginibacillus kocurii [85,86][86], Rhizobium sp. [87], Micrococcus species [88], Arthrobacter sp. [89] and Rhodococcus sp. [90].

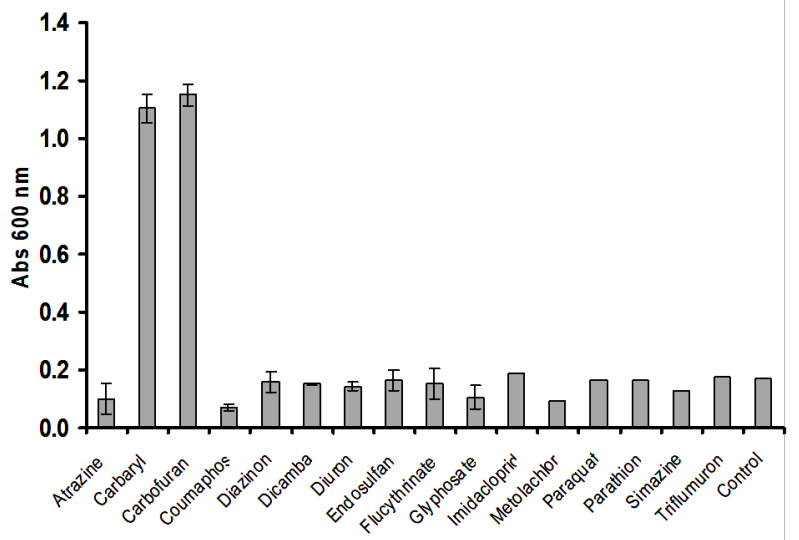

Fig. 8. Growth of Serratia sp. strain Amr-4 on various pesticides. Error bars are \pm standard deviation $(n=3)$.

\section{CONCLUSION}

The carbamate herbicides carbofuran and carbaryl can be used as carbon sources for growth by a local Mo-reducing bacterium. Serratia sp. strain Amr-4 has been provisionally identified as the bacterium that caused the outbreak. It is the first time that a molybdenum-reducing bacterium capable of thriving on carbofuran and carbaryl has been discovered in nature. The bacterium is most effective in converting molybdate to Mo-blue when the $\mathrm{pH}$ is between 6.0 and 6.8 and the temperature is between 30 and 34 degrees Celsius. When it comes to molybdate reduction, glucose was shown to be the most effective electron donor, followed by maltose and sucrose, which came in second and third, respectively, and d-mannitol and d-adonitol, which came in last and last, respectively. A phosphate concentration of 2.5-7.5 mM as well as molybdate concentrations of 20-30 mM are also required in this experiment. The Mo-blue generated by the novel Mo-reducing bacteria has an absorption spectrum that is identical to that of a reduced phosphomolybdate, and its absorption spectra is comparable to that of previous Mo-reducing bacteria. Mercury, copper, silver, and lead all decreased molybdenum reduction by $73.3,50.1,50.1$, and 20.7 percent, respectively, when used at 2 parts per million (ppm) mercury, copper, silver. The capacity of this bacterium to detoxify a wide range of toxicants is greatly sought after, making it a valuable bioremediation agent. We are now working on the purification and characterization of the molybdenum-reducing enzyme isolated from this bacterium.

\section{REFERENCES}

1. Mustafa G, Mahboob S, Al-Ghanim KA, Sultana S, Al- Balawi HFA, Sultana T, et al. Acute toxicity I: effect of profenofos and triazophos (organophosphates) and carbofuran and carbaryl (carbamates) to Labeo rohita. Toxicol Environ Chem. 2014;96(3):466-73.
2. Baligar PN, Kaliwal BB. Temporal effect of carbofuran, a carbamate insecticide in the interruption of estrous cycle and follicular toxicity in female Swiss albino mice. Bull Environ Contam Toxicol. 2003;71(2):422-8.

3. Ramanand K, Sharmila M, Singh N, Sethunathan N. Metabolism of carbamate insecticides by resting cells and cell-free preparations of a soil bacterium, Arthrobacter sp. Bull Environ Contam Toxicol. 1991;46(3):380-6.

4. Fahmy MAH, Fukuto TR, Myers RO, March RB. The selective toxicity of new N-phosphorothioylcarbamate esters. J Agric Food Chem. 1970;18(5):793-6.

5. P. RZ, Taylor. Structure and Function of Cholinesterases. In Toxicology of Organophosphates and Carbamate Compounds 2006;161-86.

6. Carbajo JB, Perdigón-Melón JA, Petre AL, Rosal R, Letón P, García-Calvo E. Personal care product preservatives: Risk assessment and mixture toxicities with an industrial wastewater. Water Res. 2014;72:174-85.

7. Qi P, Wang J, Wang X, Wang Z, Xu H, Di S, et al. Sensitive and selective detection of the highly toxic pesticide carbofuran in vegetable samples by a molecularly imprinted electrochemical sensor with signal enhancement by AuNPs. RSC Adv. 2018;8(45):25334-41.

8. Mansano AS, Moreira RA, Dornfeld HC, Diniz LGR, Vieira EM, Daam MA, et al. Acute and chronic toxicity of diuron and carbofuran to the neotropical cladoceran Ceriodaphnia silvestrii. Environ Sci Pollut Res. 2018;25(14):13335-46.

9. Saini R, Kumar P, Hira SK, Manna PP. Evaluation of carbofuranmediated toxicity against human lymphocytes and red blood cells in simulated wastewater degraded by coagulation-flocculation. Environ Sci Pollut Res. 2017;24(18):15315-24.

10. Purushothaman BP, Kuttan R. Protective effect of curcumin against carbofuran-induced toxicity in wistar rats. J Environ Pathol Toxicol Oncol. 2017;36(1):73-86.

11. Abdel-Mobdy YE, El-Beltagi HS, Abdel-Mobdy AE. Alleviation of carbofuran toxicity effect by parsley on lipids profile of male albino rats. Fresenius Environ Bull. 2017;26(7):4764-73.

12. Moreira RA, da Silva Mansano A, Rocha O. The toxicity of carbofuran to the freshwater rotifer, Philodina roseola. Ecotoxicology. 2015;24(3):604-15.

13. Fahmy MAH, Fukuto TR, Myers RO, March RB. The selective toxicity of new N-phosphorothioylcarbamate esters. J Agric Food Chem. 1970;18(5):793-6.

14. Njoku VO, Islam MA, Asif M, Hameed BH. Preparation of mesoporous activated carbon from coconut frond for the adsorption of carbofuran insecticide. J Anal Appl Pyrolysis. 2014;110(1):17280 .

15. Varshney KG, Gupta A, Singhal KC. The adsorption of carbofuran on the surface of antimony(V) arsenosilicate: a thermodynamic study. Colloids Surf Physicochem Eng Asp. 1995;104(1):7-10.

16. Singh RP, Kumari K, Saxena SK. Adsorption thermodynamics of carbofuran on acid and base saturated soils. Ecotoxicol Environ Saf. 1987 Apr 1;13(2):253-60.

17. $\mathrm{Xu} \mathrm{J}$, Hong Q, Hong $\mathrm{Y}$, Li S. Isolation, identification and degradation of carbofuran-degrading strain CFDS-1. Chin J Appl Environ Biol. 2011;17(2):237-42.

18. Yan Q-X, Hong Q, Han P, Dong X-J, Shen Y-J, Li S-P. Isolation and characterization of a carbofuran-degrading strain Novosphingobium sp. FND-3. FEMS Microbiol Lett. 2007;271(2):207-13.

19. Xu JH, Wu J, Hong Q, Zhang ZL, Li SP. Construction of doublelabelled carbofuran-degrading bacterium Sphingomonas sp. CDS1. Wei Sheng Wu Xue Bao. 2006;46(4):613-7.

20. Karpouzas DG, Morgan JAW, Walker A. Isolation and characterization of 23 carbofuran-degrading bacteria from soils from distant geographical areas. Lett Appl Microbiol. 2000;31(5):353-8.

21. Feng X, Ou L-T, Ogram A. Plasmid-mediated mineralization of carbofuran by Sphingomonas sp. strain CF06. Appl Environ Microbiol. 1997;63(4):1332-7.

22. Smedley PL, Kinniburgh DG. Molybdenum in natural waters: A review of occurrence, distributions and controls. Appl Geochem. 2017 Sep 1;84:387-432. 
23. Battogtokh B, Lee JM, Woo N. Contamination of water and soil by the Erdenet copper-molybdenum mine in Mongolia. Environ Earth Sci. 2014;71(8):3363-74

24. Gestel CAMV, McGrath SP, Smolders E, Ortiz MD, Borgman E, Verweij RA, et al. Effect of long-term equilibration on the toxicity of molybdenum to soil organisms. Environ Pollut. 2012;162:1-7.

25. Lahann RW. Molybdenum hazard in land disposal of sewage sludge. Water Air Soil Pollut. 1976;6(1):3-8.

26. Mohiuddin KM, Zakir HM, Otomo K, Sharmin S, Shikazono N. Geochemical distribution of trace metal pollutants in water and sediments of downstream of an urban river. Int J Environ Sci Technol. 2010;7(1):17-28.

27. Pandey R, Singh SP. Effects of molybdenum on fertility of male rats. BioMetals. 2002;15(1):65-72.

28. Titenko-Holland N, Shao J, Zhang L, Xi L, Ngo H, Shang N, et al. Studies on the genotoxicity of molybdenum salts in human cells in vitro and in mice in vivo. Environ Mol Mutagen. 1998;32(3):251-

29. Chopikashvili LV, Bobyleva LA, Zolotareva GN. Genotoxic effects of molybdenum and its derivatives in an experiment on Drosophila and mammals. Tsitol Genet. 1991;25(5):45-9.

30. Ema M, Kobayashi N, Naya M, Hanai S, Nakanishi J. Reproductive and developmental toxicity studies of manufactured nanomaterials. Reprod Toxicol. 2010;30(3):343-52.

31. Yamaguchi S, Miura C, Ito A, Agusa T, Iwata H, Tanabe S, et al. Effects of lead, molybdenum, rubidium, arsenic and organochlorines on spermatogenesis in fish: Monitoring at Mekong Delta area and in vitro experiment. Aquat Toxicol. 2007;83(1):4351

32. Yamaguchi S, Miura C, Ito A, Agusa T, Iwata H, Tanabe S, et al. Effects of lead, molybdenum, rubidium, arsenic and organochlorines on spermatogenesis in fish: Monitoring at Mekong Delta area and in vitro experiment. Aquat Toxicol. 2007;83(1):4351.

33. Zhang Y-L, Liu F-J, Chen X-L, Zhang Z-Q, Shu R-Z, Yu X-L, et al. Dual effects of molybdenum on mouse oocyte quality and ovarian oxidative stress. Syst Biol Reprod Med. 2013;59(6):312-8.

34. Kesavan V, Mansur A, Suhaili Z, Salihan MSR, Rahman MFA, Shukor MY. Isolation and Characterization of a Heavy Metalreducing Pseudomonas sp. strain Dr.Y Kertih with the Ability to Assimilate Phenol and Diesel. Bioremediation Sci Technol Res. 2018 Jul 31;6(1):14-22.

35. Holt JG, Krieg NR, Sneath PHA, Staley JT, Williams ST. Bergeys Man Determinative Bacteriol. 1994;

36. Costin S, Ionut S. ABIS online - bacterial identification software, http://www.tgw1916.net/bacteria logare.html, database version: Bacillus 022012-2.10, accessed on Mar 2015. 2015.

37. Shukor MY, Lee CH, Omar I, Karim MIA, Syed MA, Shamaan NA. Isolation and characterization of a molybdenum-reducing enzyme in Enterobacter cloacae strain 48. Pertanika J Sci Technol. 2003;11(2):261-72.

38. Shukor MS, Shukor MY. A microplate format for characterizing the growth of molybdenum-reducing bacteria. J Environ Microbiol Toxicol. 2014;2(2):1-3.

39. Yunus SM, Hamim HM, Anas OM, Aripin SN, Arif SM. Mo (VI) reduction to molybdenum blue by Serratia marcescens strain Dr. Y9. Pol J Microbiol. 2009;58(2):141-7.

40. Zhang $\mathrm{H}, \mathrm{Mu} \mathrm{W}$, Hou Z, Wu X, Zhao W, Zhang X, et al. Biodegradation of nicosulfuron by the bacterium Serratia marcescens N80. J Environ Sci Health - Part B Pestic Food Contam Agric Wastes. 2012;47(3):153-60.

41. Cycoń M, Zmijowska A, Wójcik M, Piotrowska-Seget Z. Biodegradation and bioremediation potential of diazinon-degrading Serratia marcescens to remove other organophosphorus pesticides from soils. J Environ Manage. 2013;117:7-16.

42. Iyamu EW, Asakura T, Woods GM. A colorimetric microplate assay method for high-throughput analysis of arginase activity in vitro. Anal Biochem. 2008;383(2):332-4.

43. Carpentier W, Smet LD, Beeumen JV, Brigé A. Respiration and growth of Shewanella oneidensis MR-1 using vanadate as the sole electron acceptor. J Bacteriol. 2005;187(10):3293-301.

44. Losi ME, Jr WTF. Reduction of selenium oxyanions by Enterobacter cloacae strain SLD1a-1: Reduction of selenate to selenite. Environ Toxicol Chem. 1997;16(9):1851-8.
45. Llovera S, Bonet R, Simon-Pujol MD, Congregado F. Chromate Reduction by Resting Cells of Agrobacterium radiobacter EPS-916. Appl Environ Microbiol. 1993;59(10):3516-8.

46. Chen X, Sun G, Xu M. Role of iron in azoreduction by resting cells of Shewanella decolorationis S12. J Appl Microbiol. 2011;110(2):580-6.

47. Uddin MS, Zhou J, Qu Y, Guo J, Wang P, Zhao LH Biodecolorization of azo dye acid red B under high salinity condition. Bull Environ Contam Toxicol. 2007;79(4):440-4.

48. Auffret MD, Yergeau E, Labbé D, Fayolle-Guichard F, Greer CW. Importance of Rhodococcus strains in a bacterial consortium degrading a mixture of hydrocarbons, gasoline, and diesel oil additives revealed by metatranscriptomic analysis. 2014

49. Chaturvedi V, Kumar A. Diversity of culturable sodium dodecyl sulfate (SDS) degrading bacteria isolated from detergent contaminated ponds situated in Varanasi city, India. Int Biodeterior Biodegrad. 2011;65(7):961-71

50. Sedighi M, Vahabzadeh F. Kinetic Modeling of cometabolic degradation of ethanethiol and phenol by Ralstonia eutropha. Biotechnol Bioprocess Eng. 2014;19(2):239-49.

51. Raj J, Prasad S, Sharma NN, Bhalla TC. Bioconversion of Acrylonitrile to Acrylamide using Polyacrylamide Entrapped Cells of Rhodococcus rhodochrous PA-34. Folia Microbiol (Praha). 2010;55(5):442-6.

52. Steiert JG, Pignatello JJ, Crawford RL. Degradation of chlorinated phenols by a pentachlorophenol-degrading bacterium. Appl Environ Microbiol. 1987;53(5):907-10.

53. Shukor Y, Adam H, Ithnin K, Yunus I, Shamaan NA, Syed A. Molybdate reduction to molybdenum blue in microbe proceeds via a phosphomolybdate intermediate. J Biol Sci. 2007;7(8):1448-52.

54. Campbell AM, Campillo-Campbell AD, Villaret DB. Molybdate reduction by Escherichia coli $\mathrm{K}-12$ and its chl mutants. 1985;82(1):227-31.

55. Hori T a, Sugiyama $\mathrm{M}$ a, Himeno $\mathrm{S}$ b. Direct spectrophotometric determination of sulphate ion based on the formation of a blue molybdosulphate complex. The Analyst. 1988;113(11):1639-42.

56. Shukor MY, Ahmad SA, Nadzir MMM, Abdullah MP, Shamaan NA, Syed MA. Molybdate reduction by Pseudomonas sp. strain DRY2. J Appl Microbiol. 2010;108(6):2050-8.

57. Yoshimura K, Ishii $\mathrm{M}$, Tarutani $\mathrm{T}$. Microdetermination of phosphate in water by gel-phase colorimetry with molybdenum blue. Anal Chem. 1986;58(3):591-4.

58. Ghani B, Takai M, Hisham NZ, Kishimoto N, Ismail AKM, Tano $\mathrm{T}$, et al. Isolation and characterization of a Mo6+-reducing bacterium. 1993;59(4):1176-80.

59. Shukor MY, Habib SHM, Rahman MFA, Jirangon H, Abdullah MPA, Shamaan NA, et al. Hexavalent molybdenum reduction to molybdenum blue by S. marcescens strain Dr. Y6. Appl Biochem Biotechnol. 2008;149(1):33-43.

60. Rahman MFA, Shukor MY, Suhaili Z, Mustafa S, Shamaan NA Syed MA. Reduction of Mo(VI) by the bacterium Serratia sp. strain DRY5. J Environ Biol. 2009;30(1):65-72

61. Shukor MY, Rahman MF, Suhaili Z, Shamaan NA, Syed MA. Bacterial reduction of hexavalent molybdenum to molybdenum blue. World J Microbiol Biotechnol. 2009;25(7):1225-34.

62. Shukor MY, Rahman MF, Suhaili Z, Shamaan NA, Syed MA Hexavalent molybdenum reduction to Mo-blue by Acinetobacter calcoaceticus. Folia Microbiol (Praha). 2010;55(2):137-43.

63. Lim HK, Syed MA, Shukor MY. Reduction of molybdate to molybdenum blue by Klebsiella sp. strain hkeem. J Basic Microbiol. 2012;52(3):296-305.

64. Abo-Shakeer LKA, Ahmad SA, Shukor MY, Shamaan NA, Syed MA. Isolation and characterization of a molybdenum-reducing Bacillus pumilus strain lbna. J Environ Microbiol Toxicol. 2013;1(1):9-14.

65. Halmi MIE, Zuhainis SW, Yusof MT, Shaharuddin NA, Helmi W, Shukor Y, et al. Hexavalent molybdenum reduction to Mo-blue by a Sodium-Dodecyl-Sulfate-degrading Klebsiella oxytoca strain DRY14. BioMed Res Int. 2013;2013:e384541.

66. Othman AR, Bakar NA, Halmi MIE, Johari WLW, Ahmad SA, Jirangon $\mathrm{H}$, et al. Kinetics of molybdenum reduction to molybdenum blue by Bacillus sp. strain A.rzi. BioMed Res Int $2013 ; 2013$ 
67. Khan A, Halmi MIE, Shukor MY. Isolation of Mo-reducing bacterium in soils from Pakistan. J Environ Microbiol Toxicol. 2014;2(1):38-41.

68. Shukor MY, Halmi MIE, Rahman MFA, Shamaan NA, Syed MA. Molybdenum reduction to molybdenum blue in Serratia sp. strain DRY5 is catalyzed by a novel molybdenum-reducing enzyme. BioMed Res Int. 2014;2014.

69. Ahmad SA, Shukor MY, Shamaan NA, Mac Cormack WP, Syed MA. Molybdate reduction to molybdenum blue by an antarctic bacterium. BioMed Res Int. 2013;2013.

70. Shukor MY, Rahman MF, Shamaan NA, Syed MS. Reduction of molybdate to molybdenum blue by Enterobacter sp. strain Dr.Y13. J Basic Microbiol. 2009;49(SUPPL. 1):S43-54.

71. Shukor Y, Adam H, Ithnin K, Yunus I, Shamaan NA, Syed A. Molybdate reduction to molybdenum blue in microbe proceeds via a phosphomolybdate intermediate. 2007;7(8):1448-52.

72. Shukor MY, Rahman MFA, Shamaan NA, Lee CH, Karim MIA, Syed MA. An improved enzyme assay for molybdenum-reducing activity in bacteria. Appl Biochem Biotechnol. 2008;144(3):293300.

73. Glenn JL, Crane FL. Studies on metalloflavoproteins. V. The action of silicomolybdate in the reduction of cytochrome $\mathrm{c}$ by aldehyde oxidase. Biochim Biophys Acta. 1956;22(1):111-5.

74. Sims RPA. Formation of heteropoly blue by some reduction procedures used in the micro-determination of phosphorus. 1961;86(1026):584-90.

75. Shukor MY, Shamaan NA, Syed MA, Lee CH, Karim MIA. Characterization and quantification of molybdenum blue production in Enterobacter cloacae strain 48 using 12molybdophosphate as the reference compound. Asia-Pac J Mol Biol Biotechnol. 2000;8(2):167-72.

76. Runnells DD, Kaback DS, Thurman EM, Chappel WR, Peterson KK. Geochemistry and sampling of molybdenum in sediments, soils, and plants in Colorado. Molybdenum Environ. 1976;

77. Shukor MY, Syed MA, Lee CH, Karim MIA, Shamaan NA. A method to distinguish between chemical and enzymatic reduction of molybdenum in Enterobacter cloacae strain 48. Malays $\mathrm{J}$ Biochem. 2002;7:71-2.

78. Sugiura Y, Hirayama Y. Structural and electronic effects on complex formation of copper(II) and nickel(II) with sulfhydrylcontaining peptides. Inorg Chem. 1976;15(3):679-82.

79. Zeng G-M, Tang L, Shen G-L, Huang G-H, Niu C-G. Determination of trace chromium(VI) by an inhibition-based enzyme biosensor incorporating an electropolymerized aniline membrane and ferrocene as electron transfer mediator. Int J Environ Anal Chem. 2004;84(10):761-74.

80. Shin D-H, Kim D-U, Seong C-N, Song H-G, Ka J-O. Genetic and phenotypic diversity of carbofuran-degrading bacteria isolated from agricultural soils. J Microbiol Biotechnol. 2012;22(4):448-56.

81. Plangklang $\mathrm{P}$, Reungsang A. Bioaugmentation of carbofuran residues in soil by Burkholderia cepacia PCL3: A small-scale field study. Int Biodeterior Biodegrad. 2011;65(6):902-5.

82. Yan Q-X, Hong Q, Han P, Dong X-J, Shen Y-J, Li S-P. Isolation and characterization of a carbofuran-degrading strain Novosphingobium sp. FND-3. FEMS Microbiol Lett. 2007;271(2):207-13.

83. Kim IS, Ryu JY, Hur HG, Gu MB, Kim SD, Shim JH. Sphingomonas sp. Strain SB5 degrades carbofuran to a new metabolite by hydrolysis at the furanyl ring. J Agric Food Chem. 2004;52(8):2309-14.

84. Desaint S, Hartmann A, Parekh NR, Fournier J-C. Genetic diversity of carbofuran-degrading soil bacteria. FEMS Microbiol Ecol. 2000;34(2):173-80.

85. Naqvi TA, Armughan A, Ahmed N, Ahmed S. Biodegradation of carbamates by Pseudomonas aeruginosa. Minerva Biotecnol. 2013;25(4):207-11.

86. Naqvi TA, Kanhar NA, Shar AH, Hussain M, Ahmed S. Microcosm studies for the biodegradation of carbaryl in soil. Pak J Bot. 2011;43(2):1079-84.

87. Hashimoto M, Fukui M, Hayano K, Hayatsu M. Nucleotide sequence and genetic structure of a novel carbaryl hydrolase gene (cehA) from Rhizobium sp. strain AC100. Appl Environ Microbiol. 2002;68(3):1220-7.

88. Doddamani HP, Ninnekar HZ. Biodegradation of carbaryl by a Micrococcus species. Curr Microbiol. 2001;43(1):69-73.
89. Hayatsu M, Hirano M, Nagata T. Involvement of two plasmids in the degradation of carbaryl by Arthrobacter sp. strain RC100. App Environ Microbiol. 1999;65(3):1015-9.

90. Larkin MJ, Day MJ. The metabolism of carbaryl by three bacterial isolates, Pseudomonas spp. (NCIB $12042 \&$ \& 12043) and Rhodococcus sp. (NCIB 12038) from garden soil. J Appl Bacteriol. 1986;60(3):233-42. 